\title{
Menyibak Masa Lalu, Menggapai Masa Depan Pasar Modal Indonesia Menuju Milenium III
}

\author{
Nindyo Pramono
}

\begin{abstract}
Entering global era nowadajs, Money Market should be directed to be competitive and it must be efficient in its management: Becoming an established Money Market in' the competition and has high efficient in its management, the next five years the development of Indonesia Money Market is focused in developing the infrastructure and Money Market. The Objectives are restructuring stock exchange, LPK and LPP in improving efficiency and the power on competition of Indonesia Money Market and ascertaining LPK stock exchange and certainly LPP is ready to face the dynamic market changes.
\end{abstract}

\section{Pendahuluan}

Bagi sebagian Pasar Modal (Capital Market) adalah makhluk yang ditakuti, karena begitu tertutup dan sulit dipahami, bahkan ada yang menyebutnya tidak ada bedanya dengan "gambling". Bagaimana orang awam akan tidak mengatakan pasar modal adalah "gambling" karena hanya dengan modal awal di bawah duapuluhan rupiah, seseorang berhasil bermain saham di pasar modal dan kini telah melakukan transaksi milyaran rupiah sehari. Akan tetapi dari segi bisnis, pasar modal merupakan seni dan bidang yang sangat mengasyikkan untuk ditekuni karena di samping bisa dijadikan sebagai sumber pendapatan dan sarana investasi bagi kalangan yang telah mengerti makna yang terkandung di dalamnya, pasar modal juga mengandung unsur-unsur psikologis yang kadangkala memang sulit diprediksi."

Bagi sebagian masyarakat yang.lain pasar modal adalah sarana investasi dalam berbagai efek, seperti saham, obligasi, obligasi konversi, opsi, waran dan sebagainya bersama-sama dengan perbankan. ${ }^{2}$ Itulah sebenarnya makna yang terkandung di dalam pasar modal. Masyarakat yang mempunyai kelebihan dana yang ingin memanfaatkan pasar modal sebagai sarana investasi perlu

'Ang, Robbert., "Buku Pintar Pasar.Modal Indonesia (The Intelligent Guide to Indonesia Capital Market)," (FirstEdition, Mediasoft indonesia, 1997), Homepage: http://www.mediasoft-id.com.

${ }^{2}$ Tjager, I.Nyoman., "Peralihan Hak Atas Saham Melalui Pemindahbukuan unțuk Meningkatkan Efisiensi. dan Kemanan Transaksi Di Bursa Efek, "Disertasi (Yogyakarta: Úniversitas Gadjah Mada, 2003). 
memahami permasalahan investasi secara utuh mengapa harus investasi, apa risikonya bagaimana tata caranya dan selanjutnya bagaimana melakukan pilihan investasi dan sebagainya. ${ }^{3}$ Dengan demikian suatu tindakan investasi adalah tindakan yang dilakukan setelah melalui proses analisis dan investasi itu menjanjikan adanya keamanan yang memuaskan. Tindakan-tindakan yang tidak memenuhi persyaratan tersebut adalah tindakan spekulasi. If you still need the money fo finance you kids' study, don't invest in capital mareket, itulah adagium yang berlaku di dunia pasar modal.

Bagi emiten pasar modal adalah sarana untuk memperoleh tambahan modal dari masyarakat yang membeli efek di bursa. Pasar modal adalah pasar dalam pengertian abstrak, yang sekaligus merupakan pasar. konkrit. Dikatakan pasar abstrak sebab yang diperdagangkan dalam pasar modal adalah dana-dana jangka panjang yang merupakan benda abstrak. Disinilah secara teoritis orang menyebutnya "Capital market". Konkritisasi perdagangan terwujud dalam bentuk jual beli surat-surat berharga atau efek di tempat perdagangan yang disebut Bursa Efek atau Stock Exchange.

Di dalam ilmu hukum, Pasar Modal masuk dalam bagian ilmu hukum dagang. Hukum Dagang dahulu diterjemahkan sebagai hukum bagi para pedagang. Siapa yang disebut dengan pedagang menurut Vollmar adalah "die daden van koophandel uitoefende en daarvan zijn gewoon beroep maakte". Pedagang adalah orang yang menjalankan perbuatan perniagaan (daden van koophandel) Perbuatan perniagaan itu apa? Perbuatan perniagaan adalah perbuatan membeli barang atau untuk dijual lagi. Jika pengertian ini diikuti maka agen perusahaan, supplier, konsinyasi dan sebagainya tidak masuk ke dalam kualifikasi pedagang. Oleh sebab kelemahan pengertian tersebut, kemudian istilah pedagang Wetbook van Koophandel diganti dengan istilah "bedrifif" atau "perusahaan". Jadi pedagang dalam pengertian sekarang menurut terminologi hukum dagang adalah orang yang menjalanan perusahan.

Menurut sejarah pasar modal, sebagai salah satu wujud dari ekonomi kapitalistik, perdagangan efek di bursa efek sesungguhnya merupakan cara tertentu dari perusahaan yang kian berkembang sejak awal zaman kebangkitan industri di Eropa dan Amerika Serikat. Motif utamanya terletak pada masalah kebutuhan modal bagi perusahaan demi memajukan dan mengembangkan usahanya dengan menjual saham pada pemilik uang atau modal baik perorangan maupun perusahaan. Pada mulanya sasaran utama adalah mereka-mereka yang mempunyai uang atau orang-orang kaya. ${ }^{4}$

Oleh karena itu Bursa Efek memiliki fungsi utama:

1. Menciptakan pasar secara terus menerus bagi efek yang ditawarkan kepada investor;

2. Menciptakan harga yang wajar bagi efek

${ }^{3}$ Sumantoro, Pengantartentang Pasar Modal di Indonesia (Jakarta: Chalia Indonesia, 1990).

4Yayasan Lembaga Pengembangan Kreatiivitas dan Pembinaan Disiplin Masyarakat, 1990; Departemen Penerangan $\mathrm{Rl}, 1994$. 
Nindyo Pramono. Menyibak Masa Lalu, Menggapai Masa Depan Pasar Modal Indonesia...

yang dijualbelikan melalui mekanisme permintaan dan penawaran;

3. Membantu pembelanjaan dunia usaha. ${ }^{5}$

Membicarakan sejarah pasar modal dan perkembangannya di Indonesia, menarik apa yang dikatakan Putu Gede Ary Suta seperti dikutip oleh Winarto ${ }^{6}$ bahwa Pasar Modal Indonesia terkena patahan historis. Pasar Modal sekarang ini bukanlah sambungan dengan pasar modal Indonesia di masa penjajahan belanda maupun pasar modal di tahun 1950an. Pasar Modal sekarang adalah suatu bentuk lembaga yang sama sekali baru. Namun demikian, dengan menggunakan pendekatan historis yang melihat konteks sejarah dari masa lalu, masa kini dan masa yang akan datang, maka untuk memahami benang merah patahan-patahan sejarah tersebut perlu dipahami sejarah kehadiran pasar modal masa lalu di indonesia. Benang merah itu adalah semangat pasar modal, suatu kekuatan dahsyat yang hidup terus menerus, baik di kalangan ahli ekonomi, ahli hukum, politisi, kalangan birokrasi, pialang atau pedagang surat berharga dan para pemilik uang lebih. Semangat ini meminjam istilah Heraklitos - yaitu mengalir bagai air. Ada sebuah masa lalu, ada masa kini dan ada pula sebuah masa datang. ${ }^{7}$ Bagaimana Pasar Modal masa kini dan mendatang menuju era milenium akan diungkapkan dari berbagai catatan hukum di bawah ini yang mudah- mudahan akan memberikan gambaran mengenai perkembangan pasar modal di Indonesia.

Pasar Modal hadir di Indonesia sudah sejak Pemerintahan Hindia Belanda, dengan didirikannya Bursa Efek di Batavia - sekarang Jakarta- pada tanggal. 14 Desember 1912 oleh De Vereniging voor de Effectenhandel. Jual beli efek pada waktu itu sudah berlangsung sejak 1880 , namun perdagangan saham dan obligasi dilakukan tanpa organisasi resmi sehingga catatan transaksinya tidak lengkap. Pada 1892 , perusahaan Cultuurmaatschappij Goalpara yang berkantor di Batavia mengeluarkan prospektus penjualan saham dengan harga 500 gulden per saham. Empat tahun kemudian, harian Het Centrum dari Djocjacarta juga mengeluarkan prospektus penjualan saham senilai 115 gulden dengan harga perdana 100 gulden per saham. Selain kedua perusahaan itu, beberapa perusahaan perkebunan juga mengeluarkan prospektus untuk mendapatkan dana dari masyarakat, tetapi tidak jelas apakah saham-saham itu diperjualbelikan. Menurut dugaan yang banyak diperjualbelikan di Hindia Belanda waktu itu adalah saham dan obligasi yang tercatat di Bursa Amsterdam yang dimiliki oleh investor yang ada di Batavia, Surabaya dan Semarang. Di samping itu juga diperdagangkan sertifikat saham (certificaat van aandelen) dan deposi-

${ }^{5}$ Sutton, David, Understanding The Stock Market (Chicago: Probus Publising Company, Illionis, 1989) Usman, Marzuki, dkk, ABC Pasar Modal Indonesia (Jakarta: Kerjasama antara lembaga Pengembangan Perbankan Indonesia dengan Ikatan Sarjana Ekonomi Indonesia Cabang Jakarta, 1990).

${ }^{6}$ Winarto, Jasso, Pasar Modal Indonesia Retrospeksi Lima Tahun Swastanisasi BEJ (Jakarta: Pustaka Sinar Harapan-Jakarta Stock Exchange, 1997).

? lbid 
tory receipt yang diterbitkan oleh Administratie Kantoor Belanda serta'efek Belanda lainnya, seperti ACF Industri, American Motors, Aanaconda Copper, Bethlehem Steel1997.8

Tujuan pendirian Bursa Efek di Batavia waktu itu adalah dalam rangka memupuk sumber pembiayaan bagi perkebunan milik Belanda yang tumbuh secara besar-besaran di Indonesia dan untuk menampung efek-efek yang dimiliki oleh orang Belanda yang dijualbelikan di Bursa Amsterdam di samping itu juga menampung saham dan obligasi perusahaan perkebunan Belanda yang beroperasi di Indonesia dan sertifikat saham (certificaat van aandelen) serta depository receipt perusahaan Amerika yang diterbitkan di Administratie Kantoor di Belanda sebagai upaya menerobos hambatan atas sahamsaham dengan nominal besar yang sulit dijangkau dan diperjualbelikan di Bursa Amsterdam. ${ }^{9}$

Perlu dijelaskan bahwa yang dimaksud dengan sertifikat saham adalah terjemahan dari certificaat van aadelen, suatu terminologi yang khusus: dikenal oleh sistem hukum Belanda yang kalau diterjemahkan ke dalam bahasa Inggris secara harfiah menjadi share certificate yaitu selembar kertas yang to certify orang yang disebut di dalam surat tersebut adalah the owner of sejumlah saham seperti yang tercatat dalam register perseroan. Namun terjemahan ini lalu menjadi tidak cocok atau tidak pas. Mengapa demikian? Karena certificaat van aandelen adalah sama pengertiannya dengan pecahan saham menurut versi Undang-undang Nomor 1 Tahun 1995 tentang Perseroan Terbatas (UUPT) di Indonesia, bukan sama pengertiannya dengan "saham" atau dalam bahasa Belanda disebut aandel atau share atau stock dalam bahasa Inggris sedangkan depository receipt atau di Belanda lebih dikenal dengan sebutan depotfractir bewijzen atau participatiebewijs yang diterbitkan oleh Belegging Maatschappij atau Belegging Fonds atau Administratie Kantoor di indonesia sama pengertiannya dengan Unit Penyertaan yang diterbitkan oleh Lembaga Reksa Dana versi UUPT atau di Negaranegara yang menganut sistem hukum Anglo Saxon sama pengertiannya dengan instrumen yang disebut Stock Unit atau Unit atau Unit Trust. ${ }^{10}$

Dengan berkembangnya Bursa efek di Batavia, Pemerintah Hindia Belanda kemudian mendirikan Bursa Efek di Surabaya dan Semarang. Keberhasilan ini telah menarik perhatian kalangan Bankir Belanda untuk ambil bagian dalam kegiatan bursa sebagai makelar atau broker. Namun menjelang Perang Dunia II pada 1939 keadaan suhu politik di Eropa mulai menghangat terutama dengan memuncaknya kekuasaan Hilter, maka untuk menghindari hal-hal yang tidak

${ }^{8} \mathrm{Ibid}$. Lihat juga dalam Sumantoro, Pengantar Tentang Pasar Modal di Indonesia (Jakarta: Ghalia Indonesia, 1990).

'Sumantoro, ibid. Lihat juga dalam Smallen de. B, Effecten bedriff, en Effecten verkeer(Amsterdam: JH. De Bussy., bv, 1975). Lihat juga dalam Usman, Marzuki, dkk, op.cit.

${ }^{10}$ Houben, Het Certificaat (N.V.H. Van der Marck's Uitgeversimij Roermond, 1951). Lihat juga dalam Koetin,EA., Analisa Pasar Modal (Jakarta: Pustaka Sinar Harapan, 1993). 
diinginkan Pemerintah Hindia Belanda memutuskan untuk memusatkan perdagangan efek di Jakarta saja. Untuk Bursa Efek di Surabaya dan Semarang ditutup. Dengan pecahnya Perang Dunia II, kegiatan Bursa Efek di Batavia-pun akhimya ditutup pula pada 1940. Pada tahun itu Indonesia diduduki Jepang. Pada saat pendudukan Jepang sampai sekitar perang kemerdekaan praktis kegiatan bursa terhenti sama sekali, karena banyak saham Belanda yang dimiliki musuh, khususnya orang-orang Jerman.

Sebelum pecah Perang Dunia II, sebenarnya perkembangan Pasar Modal di Hindia Belanda boleh dikatakan cukup baik. Pada waktu itu emisi efek tercatat sudah mencapai nilai sekitar NIF 1,4 milyar. Angka itu jika diindekskan dengan harga pada 1982 di Indonesiai, nilainya lebih kurang 7 triliun. Suatu jumlah yang sangat besar untuk ukuran sekarang. Efek yang diperdagangkan pada waktu itu tercatat sudah mencapai kurang lebih 250 macam efek, termasuk saham dan obligasi luar negeri.

Selanjutnya setelah Indonesia memproklamasikan kemerdekaannya pada tanggal 17 Agustus 1945, Pemerintah memandang perlu untuk membenahi dan menghidupkan kembali kegiatan Pasar Modal di Indonesia. Pada 1950 Pemerintah menerbitkan obligasi. Penerbitan obligasi ini telah mendorong pengaktifan kembali Bursa Efek di Indonesia. Untuk mengatur dan menghindari praktek perdagangan efek yang tidak benar tersebut, dikeluarkan Undangundang Darurat Nomor 13 tertanggal 1 September 1951 Tentang Bursa, yang kemudian dijadikan Undang-undang Nomor 15 Tahun 1952 tentang Penetapan Undang-undang Darurat tentang Bursa (Lembaga Negara
Tahun 1951 Nomor 79). Sebagai Undangundang (Lembaga Negara Tahun 1952 Nomor 67), selanjutnya akan disebut UU Bursa 1952 dan disusul dengan dikeluarkannya Surat Keputusan Menteri Keuangan Nomor 18973.

Berdasarkan UU Bursa 1952 jo SK. Menteri keuangan Nomor 18973 tersebut, Bursa Efek dibuka kembali di Jakarta dan diselenggarakan oleh Persatuan Pedagang Perantara Efek, yang di Belanda dikenal dengan nama Vereniging voor de Efeffectenhandel. Mesikipun pada dekade 50 an keadaan politik dan ekonomi Indonesia belum begitu stabil, namun Bursa Efek di Jakarta dapat berkembang cukup baik. Hal ini terbukti dengan semakin meningkatnya aktivitas bursa sejak Bank Industri Negara mengeluarkan pinjaman obligasi berturut-turut pada 1954, 1955 dan 1956. Para pembeli obligasi kebanyakan investor Belanda baik perorangan maupun badan hukum.

Memburuknya hubungan Indonesia Belanda, terutama mengenai sengketa Irian Barat, disusul dengan nasionalisasi perusahaan-perusahaan Belanda di Indonesia, dengan Undang-undang Nomor 86 Tahun 1958 tentang Nasionalisasi Perusahaan Belanda di Indonesia, mengakibatkan orangorang Belanda pada pulang ke tanah airnya dan meningkatnya inflasi yang kemudian mengakibatkan adanya kebijakan menurunkan nilai rupiah dari Rp. 1.000,menjadi Rp. 1,- yang berlaku pula bagi saham dan obligasi Pemerintah. Akibatnya efek tersebut tidak menarik lagi bagi investor. Akhirnya pada 1958 Bursa Efek di Jakarta ditutup kembali.

Keadaan beku ini berlangsung terus sampai 1966, yang kemudian lahir Orde Baru 
yang sedikit demi sedikit berhasil memperbaiki keadaan ekonomi Indonesia. Laju inflași yang pada akhir Orde Lama (1966) tercatat $650 \%$ berhasil ditekan. Kemudian pada 1967 dapat ditekan menjadi $312,33 \%$ dan 1968 berhasil turun menjadi 146,95\% dan pada akhir 1969 berhasil diturunkan lagi menjadi $24,75 \%$.

Dari keberhasilan pemulihan tingkat perekonomian tersebut, Pemerintah Orde Baru mulai mengadakan persiapan-persiapan untuk mengaktifkan kembali Pasar Modal di Indonesia secara bertahap. Berturut-turut pada 1968 dibentuk Tim Persiapan Pasar Uang dan Modal (Tim PPUM) yang antara lain menghasilkan:

1. Penyusunan konsep perubahan Pasal 54 KUHD, mengingat sistem hak suara pemegang saham dalam $P T$, yang berhasil mengubah sistem hak suara yang dikenal dengan sistem one share one vote pada 1971;

2. Pengusulan diterbitkannya Sertifikat Bank Indonesia yang disetujui Menteri Keuangan tahun 1970;

3. Usulan pengangkatan Pengurus PPUE yang kemudian disetujui pula tahun 1970;

4. Usulan Penerbitan Ketentuan Pokok tentang Lembaga Keuangan Non Bank dan Tata Cara Perizinan Lembaga Keuangan, yang kemudian disetujui pada tahun 1970.

Setelah tugas Tim PPUM selesai, Menteri Keuangan membentuk Badan Pembina Pasar
Uang dan Modal (Bapepam) dengan tugas antara lain mulai mempersiapkan pembentukan Lembaga Pasar Uang dan Modal dan melakukan pengawasan aktivitas Bursa Efek. Setelah segala persiapan pengaktifan kembali aktivitas Pasar Modal di Indonesia dirasa cukup, maka pada tahun 1976 Tentang Pasar Modal dan PP Nomor 25 Tahun 1976 tentang Penyertaan Modal Negara RI Untuk Pendirian Perusahaan Perseroan (Persero) Danareksa. Sebagai puncak peristiwa yang merupakan tonggak sejarah dimulainya kembali aktivitas Pasar Modal di Indonesia setelah sekian lama berhenti (sejak tahun 1958) adalah peresmian kegiatan Pasar Modal di Jalan Merdeka Selatan Jakarta pada tanggal 10 Agustus 1977 oleh Presiden Soeharto.

Namun demikian sejak tahun 1977 sampai dengan 1987 perkembangan Pasar Modal di Indonesia boleh dikatakan masih suram, karena sejak tahun 1977 sampai dengan tahun 1987 perusahaan go public hanya berhenti sampai dengan angka 24 emiten, 18 diantaranya emisi saham dan sisanya emisi obligasi." Meskipun berbagai insentif seperti perpajakan telah diberhentikan kepada para emiten yang menjual efeknya melalui Bursa Efek, namun demikian insentif itu tampaknya belum mampu mendongkrak minat perusahaan untuk go public.12

Keadaan suram tersebut telah mendorong Pemerintah pada 1988

1 Pramono, Nindyo, Sertifikasi Saham PT Go Public dan Hukum Pasar Modal di Indonesia, Cetakan Kedua (Bandung: Citra Aditya Bakti, 2001).

${ }^{2}$ Purba, Victor, Perkembangan dan Struktur Pasar Modal Indonesia Menuju Era AFTA 2003 (Jakarta: Badan Penerbit Fakullas Hukum Universitas Indonesia, 1999). 
mengeluarkan kebijakan deregulasi di bidang ekonomi, keuangan dan perbankan yang dikenal dengan paket Deregulasi 28 Oktober 1988 (Pakto 88). Segera setelah itu Keppres Nomor 52 Tahun 1976 diubah dengan Keppres Nomor 60 Tahun 1988 tentang Pasar Modal yang kemudian diubah lagi dengan Keppres Nomor 53 Tahun 1990 tentang Pasar Modal dan diikuti dengan keluamya SK Menteri Keuangan Nomor 1548/KMK.013/1990 tentang Pasar Modal yang kemudian disempurnakan dengan SK Menteri Keuangan Nomor 1199/KMK.010/1991. SK Menteri Keuangan tersebut merupakan embrio lahirnya UUPM karena keuntungankeuntungan yang ada pada SK Menteri Keuangan tersebut banyak yang kemudian menjadi ketentuan pasal-pasal di dalam UUPM. Kiblat pengaturan Pasar Modal di Indonesia tidak lagi mengacu kepada sistem hukum Belanda (Eeropa Continental System), namun sudah bergeser ke Sistem Hukum Amerika (Anglo American System). Diintrodusirnya Bapepam yang berfungsi seperti Securities Exchange Commission (SEC) di Amerika, Lembaga Reksadana yang merupakan model Unit Trust atau Mutual Fund di Amerika dan Inggris Lembaga Trustee merupakan beberapa contoh model pembangunan Pasar Modal Indonesia yang berkiblat ke hukum Amerika tersebut.

Sejak lahirnya SK Menteri Keuangan Nomor 1548/KMK.013/1990 tersebut Bursa Efek beserta LKP dan LPP sebagai SRO mulai diserahkan pengelolaannya kepada swasta berbentuk Perseroan Terbatas (PT BEJ dan PT KDEI). Bapepam menempatkan diri "murni" sebagai Pembina dan Pengawas Bursa seperti lazimnya Securities Exchange Commission (SEC) di Amerika. la tidak lagi merangkap fungsi sebagai penyelenggaraan Bursa sekaligus sebagai pengawas atau "wasit". Era ini disebut sebagai era konsolidasi pasar modal (1991-1995). Era ini diawali dengan menurunnya aktivitas di bursa sebagai akibat dari kebijakan uang ketat dan lemahnya kondisi bursa internasional. Sejak pertengahan 1993 Pasar Modal mulai mengalami peningkatan di mana Indeks harga Saham Gabungan (IHSG) di BEJ yang pada Januari 1993 mencapai 588,765. Pada 1994 IHSG BEJ mampu menembus di atas angka 600 dan namun sayang pada akhir Desember 1997 IHSG mengalami penurunan yang diakibatkan oleh krisis moneter menjadi 401,712. tidak mengherankan jika pada waktu sebelum krisis Majalah Time menyebutkan Pasar Modal Indonesia sebagai salah satu pasar modal yang paling dinamis di dunia. ${ }^{13}$ Penurunan IHSG 1977 segera berubah pada 1999 sampai dengan 2000 yang mampu menembus angka 700, namun akhir 2001 terjadi penurunan lagi akibat krisis yang tidak kunjung berakhir hingga saat ini. Kabarnya 2002 sampai saat ini keadaan juga tidak jauh berubah karena krisis moneter telah berubah menjadi krisis multidimensional. Demikian sensitifnya sentimen pasar terhadap hal-hal di luar keadaan pasar yang sangat berpengaruh terhadap fluktuasi IHSG inilah merupakan ciri khas Pasar Modal yang tidak dikenal dalam pasar-pasar yang lain.

\footnotetext{
${ }^{13}$ Syahrir, Tinjauan Pasar Modal (Jakarta: Gramedia Pustaka Utama, 1995).
} 
Tabel 1

Indeks harga Saham gabungan

Periode 1989 - Maret 1997

\begin{tabular}{|c|l|l|c|}
\hline \multirow{2}{*}{ Periode } & \multicolumn{3}{|c|}{ Bursa Efek Jakarta } \\
\cline { 2 - 4 } & Tertinggi & Terrendah & Akhir \\
\hline 1989 & 507,400 & 274,090 & 229,069 \\
1990 & 681,940 & 371,200 & 417,799 \\
1991 & 427,020 & 224,710 & 247,039 \\
1992 & 331,050 & 246,950 & 274,033 \\
1993 & 588,760 & 273,300 & 558,076 \\
1994 & 612,888 & 447,040 & 469,640 \\
1995 & 519,175 & 414,209 & 513,847 \\
1996 & 637,432 & 512,478 & 637,432 \\
1997 & 740,883 & 339,536 & 401,712 \\
1998 & 554,107 & 256,834 & 298,038 \\
1999 & 716,460 & 372,318 & 676,919 \\
2000 & 703,483 & 404,115 & 416,321 \\
2001 & 458,952 & 360,449 & 381,050 \\
\hline
\end{tabular}

Sumber: Victor Purba, 2000; Fact Book 2001, JSX

Dari segi jumlah emiten, volume perdagangan dana saham yang tercatat sejak 1988 sampai dengan 2003 secara keseluruhan tercatat adanya peningkatan yang cukup bagus. Di bawah ini disajikan pasang surut perkembangan jumlah Emiten dan Volume Perdagangan Saham di Bursa Efek Jakarta sejak 1988 sampai dengan 2003 (Mei 2003).
Tabel 2 Jumlah Emiten dan Volume Perdagangan Bursa efek Jakarta Tahun 1988 - Mei 2003

\begin{tabular}{|l|l|c|c|}
\hline Tahun & $\begin{array}{c}\text { Jumlah } \\
\text { Emiten }\end{array}$ & $\begin{array}{c}\text { Volume } \\
\text { Perdagangan }\end{array}$ & $\begin{array}{c}\text { Saham } \\
\text { Terdaftar }\end{array}$ \\
\hline 1988 & 24 & 6.944 .592 & 72.844 .043 \\
1999 & 56 & 95.791 .539 & 432.839 .874 \\
1990 & 123 & 702.587 .441 & 1.779 .936 .549 \\
1991 & 139 & $1,007.920 .460$ & 3.729 .481 .279 \\
1992 & 153 & 1.706 .269 .484 & 6.253 .916 .082 \\
1993 & 172 & 3.844 .03 .699 & 9.787 .393 .323 \\
1994 & 217 & 5.292 .580 .825 & 23.8454 .339 .821 \\
1995 & 238 & 10.646 .444 .247 & 45.794 .658 .125 \\
1996 & 253 & 29.527 .727 .838 & 77.240 .833 .399 \\
1997 & 282 & 76.599 .170 .013 & 135.668 .883 .612 \\
1998 & 288 & 90.620 .529 .970 & 170.549 .123 .166 \\
1999 & 277 & 178.486 .582 .779 & 846.131 .138 .504 \\
2000 & 287 & 134.531 .333 .895 & 1.186 .306 .672 .213 \\
2001 & 316 & 148.381 .308 .444 & 885.240 .510 .319 \\
2002 & 331 & 171.207 .351 .815 & 939.544 .513 .105 \\
2003 & 331 & 28.542 .149 .709 & 942.546 .707 .357 \\
& & & \\
\hline
\end{tabular}

Sumber: Bank Indonesia, 2003

\section{Catatan Hukum Perkembangan Pasar Modal menuju Melenium III}

\section{Aspek Kelembagaan SRO}

Jika semenjak 1988 sampai dengan Mei 2003 dari sisi perusahaan yang "go public" dan volume perdagangan serta jumlah saham yang didaftarkan di Bursa Efek Jakarta Pasar Modal Indonesia dapat dikatakan telah menunjukkan perkembangan yang menggembirakan 
namun demikian tidak berarti bahwa Pasar Modal Indonesia tidak menghadapi persoalan-persoalan hukum dan kelembagaan yang masih menyisakan permasalahan tersendiri. Jika hal ini dibiarkan maka dari sisi hukum bisnis cepat atau lambat akan dapat membawa suasana pasar ke suasana yang jauh dari rasa aman dan tenteram. Padahal Pasar Modal yang wajar, teratur dan efisien adalah Pasar Modal yang mampu memberikan rasa aman dan tingkat perlindungan hukum yang memadai bagi para investor. ${ }^{14}$

Satu catatan hukum yang dapat dikemukakan di sini adalah sehubungan dengan bentuk hukum PT bagi Bursa Efek dan $S R O$ lainnya (LKP dan LPP). Kelembagaan PT sebagai pengelola Bursa Efek, LPK dan LPP telah menimbulkan perdebatan oleh para ahli hukum bisnis karena hal ini dipandang kurang lazim atau menyalahi sistem. Pada masa penjajahan dahulu Bursa Batavia dikelola oleh Vereniging voor de Effectenhandel yaitu Persatuan Perdagangan Perantara Efek dan Indonesiapun mempunyai lembaga seperti itu. Mengapa pengelola Bursa Efek dan SRO lainnya bukan PPPE seperti zaman penjajah dahulu? Apa keberatannya? Itulah yang sejak semula dipertanyakan oleh para ahli hukum bisnis. Kesannya memang hanya persoalan kelembagaan yang dapat dipandang kurang begitu penting atau substansial jika dilihat dari fungsi utama Bursa Efek. Namun seperti diketahui PT menurut asasnya mempunyai karakteristik sebagai asosiasi modal, profit oriented dan mempunyai organ RUPS yang berkedudukan sebagai pemegang kekuasaan tertinggi dalam struktur PT. ${ }^{15}$ Padahal lazimnya Bursa Efek dan SRO lainnya dimanapun adalah lembaga yang non profit motive atau nirlaba dan independen. Adakah PT yang merupakan lembaga nirlaba menurut sistem hukum Indonesia? Itulah yang menjadi maslah yang oleh sementara ahli hukum bisnis dipandang sebagai telah menyalahi sistem. Dipertanyakan pula tepatkah Bursa Efek dan SRO lainnya sebagai lembaga "independen" yang berfungsi sebagai penyelenggara bursa dan penyelenggara proses kliring dan penjaminan serta penyelesaian dan penyimpanan berbentuk hukum PT dengan karakteristik seperti diuraikan di atas?

Memang di Amerika Serikat dikenal tipe perseroan yang nirlaba (Types of Nonprofit Corporations). Berdasarkan Undang-undang PT California (California Corporation Code) dikenal ada tiga kategori PT Nonprofit yaitu: "nonprofit public benefit", "nonptofit mutual benefit" dan "nonprofit relegious". Pada umumnya, perseroan "nonprofit public benefit" dan relegious didirikan untuk tujuan

\section{${ }^{14}$ Tjager, op. cit}

${ }^{15}$ Prasetya, Rudhy, Kedudukan Mandin Perseroan Terbatas Disertai Dengan Ulasan Menurut Undangundang No. 1 Tahun 1995 (Bandung: Citra Aditya Bakti, 1995). Lihat juga dalam Schilfgaarde, Van de BVen de NV (Achtste Druk, Gouda Quint, BV, Arnhrm, 1990). Lihatjuga dalam Slagter, Copendium van het Obdemermings Recht ( 5e Druk, Kluwer, Deventer, 1990). Lihat juga dalam Soekardono, Hukum Dagang Indonesia, Jilid I, Bagian II (Jakarta: Rajawali Press, 1983). Lihat juga dalam Pramono, Nindyo, "Optimalisasi Pengembalian Dana Hasil Kejahatan Ekonomi dan KKN Melalui Out of Court Settlement", Makalah (Yogyakarta:Tidak Dipublikasikan, 2003). 
"kepentingan umum" dan "keagamaan" di mana aset perseroan tidak boleh ditarik kembali (irrevocably) dan hanya didedikasikan untuk tujuan amal atau kepentingan umum, untuk perseroan "nonprofit mutual benefit" didirikan untuk manfaat dari para anggota persero. Pada umumnya perseroan yang terakhir ini dijijinkan untuk membagikan aset perseroan kepada setiap anggota perseroan atau dikelola untuk manfaat para anggotanya. ${ }^{16}$ Model ini sepertinya mirip dengan Foundation atau Charitable Trust di Amerika atau Stichting di Belanda, tapi dikelola dengan model Korporasi.

Namun pemilihan bentuk hukum PT untuk Bursa Efek, LKP dan LPP sebagai lembaga SRO tidak mengadopsi model Amerika tersebut. PT Bursa Efek Jakarta, PT KPEI sebagai LKP maupun PT KSEI sebagai LPP tetap mengacu dan tunduk kepada sistem hukum PT Indonesia yang masih berkiblat kepada sistem hukum Belanda, sehingga dari sudut teoritis tetap menyisakan persoalan yuridis seperti dikemukaan di atas. .

Selanjutnya bagaimana UUPM mengatur mengenai kelembagaan SRO ini. Seperti dikemukakan di muka UUPM mensyaratkan bahwa SRO berbentuk perseroan merupakan lembaga yang tidak bertujuan mencari laba. Apakah dengan demikian perseroan yang mengelola Bursa Efek, LKP dan LPP adalah perseroan yang non profit? Menurut sistem hukum perseroan yang dianut di Indonesia
(UUPT), Perseroan Terbatas adalah badan hukum yang didirikan berdasarkan perjanjian, melakukan kegiatan usaha dengan modal dasar yang seluruhnya terbagi dalam saham dan memenuhi persyaratan yang ditetapkan dalam undang-undang ini serta peraturan pelaksanaannya. Organ PT itu terdiri dari RUPS sebagai pemegang kekuasaan tertinggi dalam PT, Komisaris sebagai Pengawas dan Direksi sebagai Pengurus atau Pengelola PT. ${ }^{17}$ Di dalam UUPT tidak ada satu pasalpun yang melarang PT menjalankan kegiatan usaha untuk tujuan mencari untung. Justru di dalam anggaran dasar PT wajib diatur ketentuan tentang tata cara bagaimana laporan tahunan dibuat dan penggunaan laba serta pembagian deviden, yang mencerminkan bahwa justru orientasi tujuan PT adalah mencari laba. Jika ketentuan ini secara konsisten diterapkan pada PT yang menyelenggarakan kegiatan Bursa Efek, LKP dan LPP maka konsekuensinya Bursa Efek, LKP, dan LPP sebagai SRO juga boleh berorientasi mencari keuntungan. Namun demikian seperti dikemukakan di atas, hal ini tidak lazim bagi SRO yang menyelenggarakan tempat untuk kegiatan jualbeli efek, proses kliring dan penjaminan serta proses penyelesaian transaksi dan penyimpanan. SRO haruslah merupakan lembaga nirlaba yang "independen", di mana sebagai mediator tidak boleh merangkap sebagai perantara sekaligus sebagai pemain. Jika hal ini tejadi

${ }^{16}$ Whaley, Patrick, J., et-al., Advising Califomia Nonprofit Corporations, Scond Edition (USA: The Regent of the University of California, 1998). Lihat juga dalam Salamon, Lester, M., The Intemational Guide to Nonprofit Law (New York: John Wiley \& Sons, Inc., 1997). Chichester. Weinheim. Brisbane. Singapore. Toronto.

${ }^{17} \mathrm{lbid}$. Schiffgaarde, op. cit. L Lihat juga dalam Slagter, op.cit. Lihat juga dalam Prasetya, Rudhy, op.cit. Lihat jugá dálam Pramono, Nindyo, op.cit. 
dikhawatirkan SRO tidak akan independen lagi dan dampak lebih jauh Bursa dan SRO lainnya akan ditinggalkan investor.

Bursa Efek Jakarta misalnya, sebagai SRO selalu dihadapkan pada dua kepentingan yang berbeda yaitu kepentingan pemodal atau investor di satu pihak berhadapan dengan kepentingan emiten yang mencatatkan dan memperdagangkan efek di lain pihak. Jika sebagai mediator Bursa ikut bermain dalam perdagangan Efek, jelas potensi tidak netralnya sangat tinggi. Lalu bagaimana jalan keluarnya untuk mensiasati atau melakukan penyelundupan hukum (frous legis) agar SRO tidak dikesankan sebagai perseroan yang profit oriented. Jalan keluar itu antara lain dengan membuat ketentuan di dalam UUPM bahwa beberapa kewenangan RUPS seperti pengangkatan dan pemberhentian Direksi dan Komisaris dipegang oleh Bapepam, bukan RUPS listing fee dan transaction fee dalam PT tersebut yang memungkinkan menyisakan laba, ditentukan penggunaannya wajib disusun sesuai dengan ketentuan yang ditata oleh dan dilaporkan kepada Bapepam.

Sebagai institusi yang berbentuk hukum PT, SRO mempunyai beberapa karakteristik yang tidak dimiliki oleh PT pada umumnya. Karakteristik itu pertama, tampak pada kekhususan siapa yang dapat menjadi pemegang saham pada SRO tersebut. hanya Perusahaan Efek yang telah memperoleh izin usaha dari Bapepam sebagai Broker atau Pialang dan atau Underwriter dan telah memenuhi persyaratan sebagai Anggota
Bursa saja yang dapat menjadi pemegang saham pada Bursa Efek. ${ }^{18}$

Dengan demikian apabila suatu Perusahaan Efek tidak lagi menjadi Anggota Bursa karena tidak memenuhi persyaratan lagi maka perseroan tersebut secara otomatis tidak lagi berhak menjadi pemegang saham Bursa Efek dan dalam jangka waktu 3 (tiga) bulan yang bersangkutan wajib menjual sahamnya kepada Perusahaan Efek lain yang masih memenuhi syarat sebagai Anggota Bursa. Bilamana penjualan tersebut tidak berhasil artinya tidak ada yang membeli, maka Bursa Efek akan melelang saham tersebut dalam jangka waktu 3 (tiga) bulan berikutnya. Jika dalam jangka waktu 3 (tiga) bulan berikutnya ini juga tidak berhasil terjual, maka Bursa Efek akan membeli saham tersebut pada harga nominal.

Karakteristik kedua adalah berkaitan dengan pemilihan Direksi dan Komisaris Bursa Efek. Pemilihan Direksi dan Komisaris Bursa Efek juga sangat berbeda dengan pemilihan Direksi dan Komisaris PT pada umumnya. Seperti diatur di dalam Peraturan Nomor III. A.3 tentang Persyaratan Calon Direktur dan Komisari Bursa Efek dan Surat Keputusan Ketua Bapepam Nomor: Kep-041 PM/1996, Tanggal: 17 Januari 1996, ditentukan bahwa nama Calon Direktur atau Komisaris Bursa Efek hanya dapat diajukan dalam satu paket Calon Direktur atau satu paket Komisaris oleh kelompok pemegang saham yang memenuhi syarat tertentu berdasarkan total frekuensi dan nilai

${ }^{18}$ Daniri, Mas Ahmad, "Fungsi Bursa Efek Dalam Perdagangan Saham Pasca Berlakunya Undangundang Nomor 8 Tahun 1995", Makalah Bahan Penataran/Diskusi Aspek Hukum Pasar Modal di Indonesia, Tidak dipublikasikan (Yogyakarta: Fakultas Hukum UGM, 1997). 
perdagangannya di Bursa Efek. Calon Direksi dan Komisaris tersebut wajib diajukan teriebih dahulu kepada Bapepam untuk memperoleh persetujuannya, selambat-lambatnya 21 (dua puluh satu) hari sebelum dilaksanakannya RUPS yang khusus diselenggarakan untuk itu.

Karakteristik ketiga adalah hal yang berkaitan dengan Dewan Komisaris. Berbeda dengan kelaziman yang ada pada PT pada umumnya mengenai Dewan Komisaris, bahwa di samping berfungsi sebagai pengawas atas perbuatan pengurus Direksi (beheer en beschikking daden), Komisaris Bursa Efek harus terdiri dari wakil-wakil berbagai pihak yang mempunyai kepentingan langsung dengan penyelenggaraan Bursa Efek, yaitu wakil dari Emiten, wakil Anggota Bursa, wakil Pemodal dan wakil Pemerintah.

Kekhususan-kekhususan

atau karakteristik PT SRO seperti dikemukakan di atas, tetap juga belum menjawab pertanyaan apakah PT SRO dengan karakteristik itu lalu menjadi PT nirlaba. Dengan kata lain karakteristik tersebut tetap tidak dapat dipakai sebagai kriteria perseroan nirlaba. Bagaimanapun dengan adanya kenyataan bahwa dari listing fee dan transaction fee dapat terkumpul adanya laba perseroan maka PT tersebut tidak dapat dikatakan sebagai PT yang nirlaba, menurut ketentuan yang ada seperti Peraturan Pemerintah Nomor 45 Tahun 1995 tentang Penyelenggaraan Kegiatan di Bidang Pasar Modal, justru diakui adanya laba dalam perseroan tersebut. Hal ini terbuktikan bahwa perseroan tersebut tetap merupakan perseroan yang profit oriented sejalan dengan ketentuan UUPT.

Ketentuan yang mengatur bahwa rencana anggaran tahunan Bursa Efek dan penggunaan laba Bursa Efek wajib disusun sesuai dengan ketentuan yang ditentukan Bapepam dan dilaporkan kepadanya untuk memperoleh persetujuan, PT Bursa Efek dilarang melakukan pembagian deviden kepada para pemegang saham dari laba yang diperoleh dan laba yang diperoleh harus dipergunakan untuk kepentingan. pengembangan perseroan, bukan untuk dibagi kepada para pemegang saham, dimaksudkan sebagai bentuk pembatasan sifat profit motiv tersebut. Namun demikian pembatasan ini tidak juga menjawab persoalan PT nirlaba. Pengaturan-pengaturan di atas masih menyisakan pertanyaan apakah hal tersebut justru tidak akan menimbulkan kerancuan dan kontradiksi antara UUPT dengan UUPM? Bukankah UUPT adalah umbrela act dari seluruh persoalan hukum yang menyangkut masalah perseroan dengan segala permasalahan? Jika terjadi kontradiksi, manakah yang harus dimenangkan? Akankah berlaku adagium "lex spesialis derogat legi generalis? Jika berlaku apakah untuk keseluruhan atau hanya untuk hal-hal tertentu saja?

Dari sudut pandang UUPT, pembatasan tersebut memang tidak dilarang. Pasal 127 UUPT menyebutkan bagi perseroan yang melakukan kegiatan tertentu di bidang pasar modal berlaku ketentuan undang-undang PT, sepanjang tidak diatur lain dalam peraturan perundang-undangan di bidang Pasar Modal. Di dalam penjelasannya disebutkan bahwa pada dasarnya terhadap perseroan yang melakukan kegiatan tertentu di bidang Pasar Modal berlaku ketentuan dalam undangundang ini. Namun demikian mengingat kegiatan perseroan tersebut mempunyai sifat tertentu yang berbeda dengan perseroan pada umumnya, maka perlu dibuka kemungkinan 
adanya pengaturan khusus terhadap perseroan tersebut. pengaturan khusus dimaksudkan antara lain mengenai sistem penyetoran modal, hal yang berkaitan dengan pembelian kembali saham perseroan dan hak suara serta penyelenggaraan RUPS. Pasal 127 inilah yang dipandang sebagai peluang (escape clausule) untuk membuat aturan yang spesifik berkenaan dengan bentuk hukum PT bagi Bursa Efek LKP dan LPP menurut UUPM. Sampai di sini tampaknya kerancuan atau kontradiksi itu dapat dijembatani. Namun karakteristik tersebut ternyata juga masih menyisakan persoalan hukum sebagai berikut.

Jika seandainya pada suatu saat ada sementara pemegang saham PT SRO yang karena sesuatu hal tidak sependapat dengan keputusan otoritas Bursa misalnya keputusan Bapepam tentang Penerapan Modal Kerja Bersih Disesuaikan (MKBD). kemudian RUPS PT berdasarkan suara mayoritas memutuskan untuk membubarkan PT Bursa Efek, atau LKP atau LPP, dapatkah PT tersebut bubar dengan keputusan RUPS tersebut? Persoalan lain misalnya RUPS PT BEJ memutuskan untuk melakukan Kapitalisasi Laba Ditahan (Retained Eamings Recerves), ketentuan undangundang apa yảng harus diikuti, UUPT atau UUPM? Jika mengacu kepada UUPT jo AD PT maka keputusan RUPS tersebut tidak sah, sehingga akibatnya PT Bursa Efek atau LKP atau LPP akan bubar atau keputusan RUPS tersebut harus dilaksanakan oleh Direksi PT Bursa Efek Jakarta. Namun jika mengacu kepada UUPM pembubaran Bursa Efek tidak ada ketentuannya yang jelas. Jika demikian bagaimana dengan keputusan pembubaran tersebut? Berkaitan dengan persoalan Kapitalisasi Laba Ditahan akan berhadapan dengan ketentuan Pasal 7 ayat (3) jo Pasal 9 ayat (3) UUPM Pasal 10 ayat (4) Peraturan Pemerintah No. 45 Tahun 1995, Pasal 22 butir 1 AD (Anggaran Dasar) PT. BEJ, sehingga mengacu kepada ketentuan Pasal 127 UUPT, UUPM yang harus dimenangkan.

Selanjutnya akan semudah itukah Bursa Efek atau juga LKP atau LPP sebagai SRO harus bubar dengan keputusan RUPS, hanya karena terjadinya perbedaan pendapat antara pemegang saham dengan otoritas Bursa. Konsekuensi bentuk hukum PT tampaknya RUPS tetap merupakan pemegang kekuasaan tertinggi dalam struktur PT. Apapun keputusan RUPS asal tidak menyalahi ketentuan UUPT dan $A D$, kecuali untuk hal-hal yang secara tègas diatur di dalam UUPM maka keputusan RUPS adalah sah dan harus dilaksanakan. Namun jika disetujui bahwa Bursa Efek adalah salah satu sub sektor perekonomian dan leading indicator untuk melalui kinerja perekonomian suatu negara bersama-sama dengan lembaga perbankan, maka seharusnya tidak semudah itu SRO dengan bentuk hukum PT harus bubar. Dapat dibayangkan betapa multiplier efek yang timbul sebagai akibat dari pembubaran tersebut. Itulah konsekuensi bentuk hukum PT yang masih menyisakan persoalan hukum sampai sekarang.

Dari sudut kepentingan Pasar Modal, mekanisme pembubaran PT Bursa Efek atau $S R O$ lainnya seperti itu seyogyanya tidak terjadi. Namun aturan yang melarang untuk itu juga tidak ada. Mungkin waktu itu tidak terpikirkan sama sekali oleh pembentuk undang-undang sehingga di dalam UUPM maupun peraturan pelaksanaannya sampai dengan $A D$ PT tidak ada aturan yang melarang kewenangan RUPS untuk membubarkan PT tersebut. justru RUPS 
tampaknya tetap diakui sebagai pemegang kekuasaan tertinggi dalam struktur PT SRO. Dalam hal-hal tertentu kewenangan yang harus mendapat persetujuan Bapepam hanya berkaitan dengan pengangkatan dan pemberhentian Direksi dan komisaris serta RAB Perseroan maupun penggunaan laba perseroan. Selebihnya RUPS bebas membuat keputusan.

Jika demikian, dapatkah pembubaran PT SRO berdasarkan keputusan RUPS tersebut dipandang bertentangan dengan norma hukum umum atau kebiasaan yang berlaku bagi pasar modal atau atas dasar kepentingan umum (kepentingan perekonomian suatu Negara) sehingga keputusan pembubaran tersebut harus dipandang tidak sah dan batal demi hukum? Hal ini pasti menyisakan pendebatan.

Dalam banyak hal, Penulis lebih condong kepada penerapan adagium lex specialis derogat legi generali sehubungan dengan bentukan norma hukum antara UUPT dengan UUPM dan UU lain di luar KUHP. UUPM lebih tepat untuk diperlukan sebagai UU khusus berhadapan dengan UUPT bahkan UU lain di luar UUPT seperti disebutkan di muka. Dalam banyak hal praktek Bursa memang menghendaki demikian. Masalah transaksi efek yang sekarang sudah menggunakan model scrippless trading-book entery settlement, jika dipersoalkan saat kapan kesepakatan dalam transaksi scripless trading tersebut terjadi diukur dengan Pasal 1320 ayat (1) KUHPerdata, maka akan sangat sulit untuk menentukan saat tersebut karena kesepakatan terjadi melalui mekanisme elektronik. Demikian pula masalah mekanisme perihal efek atau penentuan peralihan hak milik atas efek dalam transaksi scripless trading, jika mekanisme konvensional melalui ketentuan Pasal 613 KUHPerdata (balik nama untuk klausula op naam,endosemen untuk klausula aan order dan onder hand atau hand by hand untuk klausula aan toonder) yang dipergunakan, maka transaksi scripless akan menyisakan banyak persoalan bahkan dapat menghambat perkembangan bursa. Untuk itulah Tjager ${ }^{19}$ mengatakan bahwa Pasal 613 KUHPerdata tidak mungkin lagi diberlakukan dalam transaksi bursa yang sudah menggunakan model scripless trading-book entry settlement. Contoh lain berkaitan dengan masalah hukum pembuktian menurut Buku IV KUHPerdata. Dalam banyak hal datà elektronik dalam pola "scripless trading-book entry settlement" menuntut untuk diakui sebagai alat bukti yang sah menyimpang dari ketentuan Buku IV KUHPerdata dengan berpedoman pada Undang-undang Nomor 8 Tahun 1997 tentang Dokumen Perusahaan.

Kegiatan pasar modal sebagian besar saat ini sudah menggunakan sarana teknologi informasi baik dari segi pengadministrasian oleh para pelaku maupun pelayanan kepada nasabah serta pelaksanaan kegiatan utama usahanya. Pengaturan atas pemanfaatan teknologi informasi menjadi penting untuk memberikan kepastian hukum ketika dalam hubungan antara pelaku Pasar Modal terjadi pelanggaran atau kejahatan atau perselisihan yang memerlukan penegasan dan penyelesaian hukum.

${ }^{19}$ Tjager, op.cit. 
Kendala utama yang dihadapi oleh Pasar Modal adalah sulitnya pembuktian pelaku kejahatan sebagai akibat dari adanya hubungan hukum antar pelaku Pasar Modal dengan sarana teknologi informasi tersebut. sejauh ini belum ada landasan hukum yang kuat sehubungan dengan data dan dokumen elektronik diakui sebagai alat bukti yang sah. Peraturan perundang-undangan yang ada berkaitan dengan alat bukti adalah Pasal 1866 ayat (1) KUHAP, Pasal 184 ayat (2) dan Pasal 186 KUHAP, Pasal 1866 jo Pasal 1867 KUHPerdata dan Pasal 1 ayat (1) dan (2) UU nomor 8 Tahun 1997 tentang Dokumen Perusahaan. Semua ketentuan tersebut (kecuali UU Nomor 8 Tahun 1997 sekalipun masih sangat sumir) belum dapat mengakui data atau dokumen elektronik sebagai alat bukti yang sah. Sementara praktek transaksi efek di bursa sudah menggunakan sarana elektronik. Oleh karena itu sudah tepat jika UUPM menuntut diakui sebagai hukum khusus berhadap dengan hukum umum, seperti UUPT, KUHD, KUHPerdata, KUHP, dan KUHAP.

\section{Prospek Penerapan Demutualisasi Bursa Efek di Indonesia}

Memasuki era global dewasa ini keberhasilan industri apapun termasuk pasar modal akan sangat ditentukan oleh kemampuan daya saing produk yang dihasilkan dan sejauhmana produk tersebut dikelola secara efisien. Untuk menjadi Pasar Modal yang mempunyai daya saing dan efisiensi yang tinggi, maka Pasar Modal harus mulai mengkaji dan memikirkan serta mengantisipasi perkembangan global tersebut agar tidak tertinggal dengan negara- negara lain khususnya di Kawasan Asia. Seperti dirumuskan di dalam Cetak Biru Pasar Modal Indonesia adalah mewujudkan Pasar Modal Indonesia sebagai penggerak ekonomi nasional yang tangguh dan berdaya saing global.

Mengacu pada visi tersebut di atas, sasaran pengembangan Pasar Modal Indonesia era lima tahun ke depan akan difokuskan pada pengembangan infrastruktur dan Pelaku pasar. Sasarannya antara lain adalah restrukturisasi Bursa Efek, LKP dan LPP untuk meningkatkan efisiensi dan daya saing Pasar Modal Indonesia dan memastikan Bursa LKP serta LPP siap menghadapi perubahan pasar yng dinamis, dengan mengembangan lembaganya masing-masing secara terpadu agar dapat menghadapi dinamika perubahan pasar dengan membentuk struktur bisnis yang fleksibel serta berorientasi strategis untuk mengembangkan kegiatan komersial dari masing-masing . lembaga tersebut.

Bertitik tolak dari sasaran pengembangan Pasar Modal Indonesia menuju era Milenium III demutualisasi Bursa Efek dan SRO lainnya akan merupakan pilihan pertama untuk mendukung tercapainya tujuan tersebut. Demutualisasi adalah perubahan struktur kepemilikan Bursa Efek dari yang semula hanya dimiliki oleh anggotanya menjadi dapat dimiliki oleh publik dan sekaligus diiringi perubahan orientasi dari non profit motive menjadi profit motive. Demutualisasi mempunyai dua model:

1. Direct Demutualization. Dalam model ini masing-masing kelembagaan Bursa Efek atau kelembagaan SRO yang lain akan melakukan demutualisasi sendiri-sendiri dengan melakukan penawaran saham 
kepada pihak lain di luar pengguna jasanya;

2. Holding Company. Dalam model ini, kelembagaan Bursa Efek dan SRO yang ada akan mendirikan Perusahaan Induk (PI) sebagai pemegang saham mayoritas mutlak (100\%) dan lembaga SRO akan menjadi Anak Perusahaan (AP). PI akan melakukan penawaran sahamnya kepada publik atau go publik atau menjadi perusahaan publik, sedangkan kegiatan SRO dan atau beberapa kegiatan supporting services dilaksanakan oleh AP.

Hal-hal yang melatarbelakangi penerapan demutualisasi Bursa Efek dan SRO lainnya di Indonesia adalah: ${ }^{20}$

1. Kebutuhan dana;

2. Peningkatan Good Corporate Governance;

3. Pengembangan Produk;

4. Pengembangan Infrasruktur;

5. Peningkatan nilai Saham Bursa Efek;

6. Pengembangan pasar;

7. Sarana Pelepasan Kepemilikan Saham.

Dari 52 Bursa di dunia, 15 Bursa telah melakukan demutualisasi, di antaranya: Australia, Amsterdam, Frankfurt, Stockhlom, Singapura, Toronto, 14 Bursa hampir melakukan demutualisasi, 15 sedang mempertimbangkan secara serius untuk melakukan demutualisasi. Sejak 2000 ke depan, sekitar $79 \%$ Bursa akan melakukan demutualisasi. Hal ini menunjukkan bahwa. demutualisasi telah merupakan pilihan terbaik dalam rangka pengembangan bursa efek dengan mereposisikan dirinya menghadapi persaingan global dan efisiensi. ${ }^{21}$ Tinggal bagaimana Indonesia merespon fenomena tersebut.

Adapun model yang akan dipith Indonesia tampaknya demutualisasi sebagai salah satu alternatif pengembangan bursa efek menuju Milenium III masih memerlukan pengkajian yang mendalam khususnya berkaitan dengan peraturan perundangundangan yang ada di bidang Pasar Modal dan peraturan perundang-undangan yang terkait, seperti UUPT, UU Nomor 9 Tahun 1969 tentang BUMN, UU Nomor 5 Tahun 1999 tentang larangan Praktek Monopoli dan Persaingan Tidak Sehat (UU Anti Monopoli), UU Nomor 4 Tahun 1998 tentang Kepailitan.

\section{Aspek Penegakan Hukum}

Jika law enforcement harus diartikan seberapa banyak kasus-kasus pelanggaran dan atau kejahatan Pasar Modal telah dilakukan penindakan hukum melalui Pengadilan, maka penegakan hukum di Pasar Modal dapat dikatakan belum menggembirakan. Karena sampai saat ini belum banyak kasus-kasus bursa Pasar Modal yang sampai ke pengadilan, meskipun Bursa sudah mulai dikembangkan sejak 1977. Namun demikian jika law enforcement itu pada tataran penegakan UUPM ditingkat Otoritas Bursa seperti Bapepam Bursa Efek, LKP dan LPP,

${ }^{20}$ Tim Demutualisasi Bapepam- SRO:2001. Lihatjuga dalam Danini, "Bursa Efek Demutualisasi Kaitannya Dengan Perubahan UUPM', Makalah Lokakarya mengenai RUU Pasar Modal, 24 April 2001, Kerjasama Magister Hukum UGM-Bapepam-Jakarta Stock Exchange-University of South Carolina, 2001.

${ }^{21}$ Ibid. 
maka harus diakui bahwa Otoritas Bursa sudah mampu berbuat banyak dalam penegakan hukum di bursa Pasar Modal.

Memang kasus-kasus yang dapat diindikasikan sebagai pelanggaran dan atau kejahatan Pasar Modal sejak diberlakukannya UUPM sering kali terjadi, namun sampai saat ini jarang yang sampai ke Pengadilan. Kebanyakan sanksi yang dikenakan oleh Otoritas Bursa baik Bura Efek Jakarta maupun Bapepam hanya berupa suspend, denda dan sanksi administratif lainnya. Pada kurun waktu 1995 sampai dengan 1997 misalnya, sedikitnya tercatat 81 jenis saham yang naik tidak normal di lantai bursa, yaitu lebih dari $30 \%$ dalam satu hari transaksi. Pada tahun 1995 terdapat 40 saham yang kursnya melonjak di atas $30 \%$ dalam sehari perdagangan. Selanjutnya pada tahun 1996 tercatat 32 saham dengan gain luar biasa dalam kurun waktu sama. Pada pekan pertama April 1997 telah sembilan saham kecil yang mengalami hal serupa. Jika diambil berdasarkan persentase, terdapat 16 jenis saham yang gain antara $50-100 \%$. Bahkan tiga saham memberi gain di atas $100 \%$, yaitu saham Rimba Niaga Idola 113,33\%, Ades $125 \%$ dan Bank Pikko 207,69\%.
Tubel 3

Perubahan harga Saham dalam Seharl dengan Keiakan dI Atas 40\% 1995- 1997

\begin{tabular}{|c|c|c|c|c|c|}
\hline No & Emiten & Tgl & $\begin{array}{l}\text { Harga } \\
\text { Kmrn }\end{array}$ & $\begin{array}{l}\text { Harga } \\
\text { Pntpn } \\
\text { (Ro) }\end{array}$ & Prbhn \\
\hline i. & Bank Pikko & $8-497$ & 1.300 & 4.000 & 207,69 \\
\hline 2 & Ades Alfindo Putra Setia & $26-9-95$ & 1.000 & 2.250 & 125,00 \\
\hline 3. & Rimba Niaga Idola & $15-8-95$ & 375 & 800 & 113,33 \\
\hline 4. & Intraco Penta & $26-9-95$ & 850 & 1.700 & 100,00 \\
\hline 5. & Hitl. Prapatan SB & $18-2.97$ & 1.100 & 2.175 & 97,73 \\
\hline 6. & PrimaAlloy Steel & $18-2-97$ & 2.425 & 4.575 & 88,66 \\
\hline 7. & Nipress & $6-3-96$ & 575 & $\cdot 1.075$ & 86,96 \\
\hline 8. & Van Der Horst Ind & $3-6-96$ & 1.375 & 2.450 & 78,18 \\
\hline 9. & Lippo Pacific & $26-6-96$ & 1.125 & 2.000 & 77,78 \\
\hline 10. & - Dharmindo Adhidula & 4-1.95 & 600 & 1.000 & 66,67 \\
\hline 11. & Igarjaya & $24-3-95$ & 600 & 1.000 & 66,67 \\
\hline 12. & Suryamas Dutamakmur & $12-10-95$ & 450 & 750. & 65,00 \\
\hline 13. & Goodyear Ina & $30-3-95$ & 3.000 & 4.950 & 65,00 \\
\hline 14. & Super Mitory Utama & $14-3.96$ & 850 & 1.400 & 64,71 \\
\hline 15. & Ugahari & $11-1-95$ & 800 & 1.250 & 56,52 \\
\hline 16. & Plaza Indonesia Rty & 4895 & 1.025 & 1.600 & 56.10 \\
\hline 17. & Ultra Jaya Milk & $22-5-95$ & 1.450 & 2.200 & 51,72 \\
\hline 18. & Alumindo Perkasa & $15-10-96$ & 775 & 1.175 & 51,61 \\
\hline 19. & Bakrie Sumatra Plant & $29-8-95$ & 2.325 & 3.500 & 50,54 \\
\hline 20. & Astra Graphia & $27-9-95$ & 1.00 & 1.500 & 50,00 \\
\hline 21. & Soedarpo Corp. & $30-5-96$ & 800 & 1.200 & 50,00 \\
\hline 22. & Bank Umum Nasional & $30-8-95$ & 1.800 & 2.700 & 50,00 \\
\hline 23. & Sarasa Nugraha & $14-8-96$ & 925 & $1.375^{\circ}$ & 48,65 \\
\hline 24. & Intraco Pentra & $27-9-95$ & 575 & 850 & 47,83 \\
\hline 25. & Hotel Sahid Jaya Int'I & $2-2-95$ & 1.100 & 1.600 & 45,45 \\
\hline 26. & Holel Sahid Jaya Int'I & $19-1-95$ & 1.100 & 1.600 & 45,45 \\
\hline 27. & Sona Topas Taurism & $24-8-95$ & 1.250 & 1.800 & 44,00 \\
\hline 28 & Bank Internasional Ina & $9-4.95$ & 1.600 & 2.300 & 43,75 \\
\hline$x$ & Lippo Pacific & $3-1-96$ & 975 & 1.400 & 43,59 \\
\hline 30 & Lion Metal Works & $7-10-96$ & 925 & 1.325 & 43,24 \\
\hline 31. & Nipress & $30-1-96$ & 525 & 750 & 42,86 \\
\hline 32. & Iki Indah Kabel Ina & $28-12-95$ & 1.050 & 1.500 & 42,86 \\
\hline 33. & Fast Food Indonesia & 14496 & 2.100 & 3.000 & 42,86 \\
\hline D & Miwon Indonesia & $24-10-96$ & 1.175 & 1.675 & 42,55 \\
\hline 35 & Bayu Buana & $28-8-95$ & 1.125 & 1.600 & 42,22 \\
\hline 36. & Bumi Modern Hyatt & $31-7-95$ & 600 & 850 & 41,67 \\
\hline 37. & Modemland Realty & $26-3-97$ & 1.875 & 2.650 & 41,33 \\
\hline 38 & Ugahari & $21-2-97$ & 850 & 1.200 & 41,18 \\
\hline 39. & Keramix Indonesia A & $30-5-95$ & 1.850 & 2.600 & 40,54 \\
\hline
\end{tabular}


Serangkaian isu seperti akuisisi, stock split, rights issue, tender offer, masukan investor besar maupun corporate action lainnya menjadi penyebab utama menguatnya saham-saham tersebut di bursa. Beberapa kasus melonjaknya harga saham di lantai bursa banyak yang berbau insider information. Kasus pergerakan saham Super Indah Makmur (SIMA) pada pertengahan 1996 misalnya membuat sebagian besar pemodal terperangah. Saham yang biasanya tidak likuid dan sudah sangat murah tiba-tiba melejit. Isu yang beredar waktu itu saham akan diakuisi oleh Johannes Kotjo. Setelah dilakukan penyelidikan law enforcement yang dilakukan oleh otoritas Bursa adalah perdagangan saham SIMA dihentikan (suspend) pada sesi pertama.

Kejadian lain pada 1996 adalah kasus Bank Mashill Utama. Pada tanggal 9 April 1996 terjadi transaksi yang cukup besar dengan penjualan 38,128 juta lembar saham diikuti kenaikan harga sebesar $36 \%$ dari Rapat Paripurna 1.950 menjadi Rapat Paripurna. 2.650 dalam sehari. Lonjakan terjadi setelah beredar isu akan dilepasnya $51 \%$ saham pendiri dan akan diambilalih oleh Titik Prabowo dan Eka Tjipta Widjaja. Dari hasil penelitian BEJ kasus ini mengidentifikasikan adanya misleading information. Setelah dilakuan penyelidikan, law enforcement yang dilakukan Bapepam adalah Bank Mashill kemudian dilakukan sanksi denda sebesar Rp. 7 juta karena terlambat melaporkan informasi yang ditengarai menyesatkan tersebut.

Kasus yang cukup menghebohkan pada 1997 adalah kasus Bank Pikko. Kasus ini ditengarai merupakan indikasi adanya kejahatan Pasar Modal yang disebut market manipulation melalui cara cornering. Corner adalah sejenis manipulasi pasar dalam bentuk menguasai pasokan saham yang beredar di pasar sehingga pelakunya dapat menentukan harga saham di bursa. Dengan adanya comer ini, harga dapat direkayasa dengan cara melakukan transaksi fiktif atau transaksi semu. ${ }^{22}$ Sanksi yang diberikan oleh Bapepam terhadap bank Pikko, yaitu kepada Sdr. Benny Tjokrosaputro dan Sdr. Pendi Tjandra diwajibkan menyerahkan keuntungan yang diperoleh atas transaksi saham Bank Pikko selama kurun waktu Maret sampai dengan April 1997 masing-masing Rp. 1 miliar dan Rp. $1 / 2$ miliar ke kas negara selambatlambatnya dalam jangka waktu 14 hari. $\mathrm{Di}$ samping itu, kepada Sdr. Pendi Tjandra diminta mengundurkan diri sebagai Direktur PT. Multi Prakarsa Investama Securities. Cornering yang dilakukan oleh Bank Pikko telah melibatkan sedikitnya 54 Perusahaan Efek yang kesemuanya juga telah dikenai sanksi oleh Bapepam.

Peristiwa-peristiwa yang diindikasikan dapat menjadi kasus pada 2001 dan 2002 dapat dilihat pada Tabel 4 dan Tabel 5 di bawah ini.

22 Winarto, Jasso, PasarModal Indonesia Retrospeksi Lima Tahun Swastanisasi BEJ (Jakarta: Pustaka Sinar Harapan-Jakarta Stock Exchange, 1997). Lihat juga dalam Safitri, Indra, Independensi, Transparansi, Pengawasan Kejahatan Pasar Modal (Jakarta: Go Global Book, Safitri \& Co Publication Book Division, 1998). 
Tabel 4

Peristiwa yang Berpotènsi Menjadi Kasus Pelanggaran UUPH Tahun 2001

\begin{tabular}{|c|c|c|c|}
\hline No & Kode & Nama Emiten & Kasus. \\
\hline 1 & PTRA & $\begin{array}{l}\text { PT. Putra Surya } \\
\text { Perkasa Tbk }\end{array}$ & $\begin{array}{l}\text { Pelanggaran Pengungkapan Laporan } \\
\text { Keuangan per } 30 \text { September } 2000 \text {; } \\
\text { Perseroan tidak mengungkepkan } \\
\text { adanya faktagugatan pailityang } \\
\text { dihadapi perseroan }\end{array}$ \\
\hline 2 & SHID & $\begin{array}{l}\text { PT. Hotel Sahid } \\
\text { Internasional Tbk. }\end{array}$ & $\begin{array}{l}\text { Penggunaan dana PUT I yang tidak } \\
\text { segera direalisasikan namun } \\
\text { ditempalkan sebagai uang muka } \\
\text { nada panusahaan afiliasi }\end{array}$ \\
\hline 3 & TMPI & $\begin{array}{l}\text { PT. Agis } \\
\text { Investama Tbk. }\end{array}$ & $\begin{array}{l}\text { Keterbukaan informasi mengenai } \\
\text { rencana pengquraan dana PUT II }\end{array}$ \\
\hline 4 & LPU & $\begin{array}{l}\text { PT. LippoE } \\
\text { Net Tbk }\end{array}$ & \begin{tabular}{|l|} 
Pentrunan kinerja operasi dan \\
indikssi pelanggaran penyajian dan \\
vengungkapan laporan keuangan
\end{tabular} \\
\hline 5 & UNBN & PT. Unibank Tbk & $\begin{array}{l}\text { Restrukturisasi wesel ekspor } \\
\text { Perseroan menjadi penyertaan di PT } \\
\text { PrimaEnernilndonesia }\end{array}$ \\
\hline 6 & $\mathrm{BCMN}$ & $\begin{array}{l}\text { PT. Bank } \\
\text { Danamon Tbk }\end{array}$ & $\begin{array}{l}\text { Adanya aduan dari ahli waris ex } \\
\text { pemegang saham BDMN (Daud B } \\
\text { dan Rusli H), yailu adanya } \\
\text { Pengalihan kepemilikan } \\
\text { saham secara tidak sah dari ex } \\
\text { pernegang saham tersebut kepada } \\
\text { pihak lain }\end{array}$ \\
\hline 7 & TKIM & $\begin{array}{l}\text { PT. PK Tjiwi } \\
\text { Kimia Tbk }\end{array}$ & $\begin{array}{l}\text { Kelertambatan penyampaian LK } 2000 \\
\text { \& Tidak melaksanakan Public } \\
\text { Expose secara tepat waktu }\end{array}$ \\
\hline 8 & INKP & $\begin{array}{l}\text { PT. Indah Kiat } \\
\text { Pulp \& Paper Tbk }\end{array}$ & $\begin{array}{l}\text { Kelertambatan penyampaian LK 2000 } \\
\text { \& Tidak melaksanakan Public } \\
\text { Exposesecaratepatwaktu }\end{array}$ \\
\hline 9 & LPIN & $\begin{array}{l}\text { Multi Prima } \\
\text { Sejahtera }\end{array}$ & $\begin{array}{l}\text { Keterlambatan penyampaian LK } 2000 \\
\text { \& Tidak melaksanakan Public } \\
\text { Exoose secaratepal waktu }\end{array}$ \\
\hline 10 & INRU & $\begin{array}{l}\text { Inti Indrayon } \\
\text { Utama }\end{array}$ & $\begin{array}{l}\text { Keterlambatan penyampaian LK } 2000 \\
\text { \& Tidak melaksanakan Public } \\
\text { Expose secara tepat waktur }\end{array}$ \\
\hline 11 & UGAR & $\begin{array}{l}\text { PT. Wahana } \\
\text { Jayar Perkasa Tbk }\end{array}$ & $\begin{array}{l}\text { Keterdambatan penyampaian LK } 2000 \\
\text { \& Tidak melaksanakan Public } \\
\text { Expose secara lepat wakte }\end{array}$ \\
\hline 12 & POF! & $\begin{array}{l}\text { PT.Panca } \\
\text { Overseas } \\
\text { Finanocce Tok }\end{array}$ & \begin{tabular}{|l|} 
Keteriambatan penyampaian LK 2000 \\
\& Tidak melaksanakan Public \\
Expose secaralepat waktu
\end{tabular} \\
\hline 13. & BRPT & $\begin{array}{l}\text { PT. Barito Pasific } \\
\text { Timber Tok }\end{array}$ & $\begin{array}{l}\text { Defaoult Obligasi dan Benturan } \\
\text { kepentingan Transaksi pembelian } \\
\text { saham diPenusahaan Afliasi }\end{array}$ \\
\hline 14 & TRPK & $\begin{array}{l}\text { PT. Tranfindo } \\
\text { Perkasa Tbk }\end{array}$ & $\begin{array}{l}\text { PT. Transfindo Perkasa berencana } \\
\text { untuk melakukan alih bidang } \\
\text { usaha dan right issue. Hasil right } \\
\text { issue akan digunakan untuk akuisisi } \\
\text { penusahaan jagung dan melepas } \\
\text { isdusti trato. Pensahaan jagung } \\
\text { dimitiki oleh stand by buyer right issue } \\
\text { TRPK }\end{array}$ \\
\hline
\end{tabular}

Sumber; BEJ; 2003
Tabel 5

Peristiwa yang Berpotengi Menjadi Kasus Pelingg,uran Uupi Tahun 2002

\begin{tabular}{|c|c|c|}
\hline No. & Nama Emiten & Kasus \\
\hline 1 & PT. Timah Tbk. & $\begin{array}{l}\text { Laporan keuangan auditan tahun } 2001 \\
\text { memperoleh opini WTP tanpa } \\
\text { paragraf penjelasan, sementaratidak ada } \\
\text { perbedaan signifikan antara realisasi dan } \\
\text { proyeksi saat manajemen mengumumikan } \\
\text { Perseroan dałan kondisi sulitdan } \\
\text { merencanakan beberapa bindakan kontigensi } \\
\text { jika terjadi kondisi seperti diperkirakan } \\
\text { termesulkkemungkinan likuidasi. }\end{array}$ \\
\hline 2 & $\begin{array}{l}\text { PT. Adindo } \\
\text { Foresta Tbk. }\end{array}$ & $\begin{array}{l}\text { Selama lahun } 2002 \text { tidak membukukan } \\
\text { pendapatan dari bisnis intinya dan } \\
\text { telał melakukan penjualan aset-asetberupa } \\
\text { alat-alat beratyang selama ini } \\
\text { memberikan kontribusi pendapatan jasa sewa } \\
\text { alat berat. Akuntan tidak melakukan site visit } \\
\text { atau aset Perseroan yang menjadi andalan } \\
\text { ulama Perseroan di area yang berisiko. }\end{array}$ \\
\hline 3 & PT. Indosat Tbk. & $\begin{array}{l}\text { Rencanadivestasi saham pemerintahdi ISAT } \\
\text { yang cukup material dan dapat mempengaruh } \\
\text { hargasahan Perseroan. Untuk menghindari } \\
\text { kemungkinan adanya pihak-pihak yang } \\
\text { menanfaztkan informasi tersebut } \\
\text { BEJ melakukan suspensi efek ISAT. }\end{array}$ \\
\hline 4 & $\begin{array}{l}\text { PT. Duta Pertiwi } \\
\text { NusantaraTbk. }\end{array}$ & $\begin{array}{l}\text { Tidak mengkondisikan anak Pensahaan pada } \\
\text { laporan kevanoan interim. }\end{array}$ \\
\hline 5 & $\begin{array}{l}\text { PT.Maniy Unitama } \\
\text { Finance Tbk. }\end{array}$ & $\begin{array}{l}\text { Incikasi penyajian Penyisihan Pitutang Ragu- } \\
\text { ragu yang understated dan diragukannya } \\
\text { kolekttibilitas tagihar-tagihan Perseroan. }\end{array}$ \\
\hline 6 & $\begin{array}{l}\text { PT. Siwani Trimitra } \\
\text { Tbk. (MTII) dan) } \\
\text { PT. Siwani } \\
\text { Makmur Tbk. (SIMA }\end{array}$ & $\begin{array}{l}\text { Transaksi benturan kepentingan yaitu } \\
\text { pembelian obligasi MITI oleh S!MA dan } \\
\text { transaksi pemberian uang muka } \\
\text { kepada perusahaan afiliasi tanpa mengikuti } \\
\text { selentuan yano berlaku }\end{array}$ \\
\hline 7 & $\begin{array}{l}\text { PT. Jakarta Setibudi } \\
\text { Property }\end{array}$ & $\begin{array}{l}\text { Melakukan corporate action dengan } \\
\text { melakukan reevaluasi assel. }\end{array}$ \\
\hline
\end{tabular}

Sumber: BEJ, 2003 
Kasus yang masuk ke Pengadilan dan menarik perhatian di tahun 2000 adalah kasus saham PT Gudang Garam Tbk. sebanyak 3.000 lembar atau 6 lot, yang telah dilaporkan hilang oleh Bursa Efek Jakarta kepada Pihak Kepolisian dan kemudian dilakukan penyidikan oleh Polisi dan akhimya menjadikan Sdr. Onggo Wibowo alias Gunawan Pangestu alias Awang sebagai tersangka dan oleh Hakim Pengadilan Negeri Jakarta Selatan dijatuhi hukuman 1 (satu) tahun 4 (empat) bulan dan semua barang bukti -yang antara lainsaham yang hilang tersebut sebanyak 3.000 lembar atau 6 lot dirampas untuk negara. ${ }^{23}$

Berkenaan dengan langkah penegakan hukum seperti yang dikemukakan di atas, di dalam praktek memang ada yang mempersoalkan mengapa terkesan Otoritas Bursa baik BEJ maupun Bapepam lebih mengedepankan penyelesaian jalur non litigasi dari pada jalur litigasi. Hasan Zein Mahmud seorang mantan Direktur Utama BEJ menyatakan bahwa tindakan seseorang yang menciptakan gambaran semu mengenai perdagangan saham di bursa efek merupakan tindakan pidana. Karena itu, pelanggarnya tidak cukup hanya dikenakan sanksi administratif tetapi harus dengan sanksi pidana pula. Dia mengkhawatirkan, kalau hanya sanksi administratif, orang akan berani melakukan tindak pidana. ${ }^{24}$

Dari sudut pendekatan yuridis formal, pendapat Hasan Zein Mahmud tampaknya dapat dipahami. Namun dari sudut pendekatan praktek hukum bisnis masih terbuka peluang untuk dipersoalkan. Bapepam sendiri dalam rangka penegakan hukum di pasar modal, tampaknya lebih memilih mengambil kebijakan menitikberatkan unsur edukatif dan memelihara kesinambungan perdagangan dari pada secara zakelijk membawa setiap kasus bursa langsung ke meja hijau. Dalam rangka penegakan hukum kasus-kasus bisnis pada umumnya, termasuk di dalamnya kasus-kasus pasar modal memang layak untuk dipertimbangkan untuk "tidak harus" semuanya berakhir di Pengadilan. Misalnya kasus-kasus bursa di atas, pendekatan edukatif dan demi memelihara kesinambungan perdagangan memang layak untuk menjadi pertimbangan penentuan sanksi atas pelanggaran yang terjadi. Dapat dibayangkan, jika pendekatan yuridis formal yang harus dikedepankan dan hukum harus diterapkan secara zakelijk pasar modal dapat lumpuh karena itu mengingat begitu banyaknya pialang yang tersangkut. Ambil contoh, dalam kasus Bank Pikko, Perusahaan Efek yang terlihat dalam "goreng menggoreng saham" tersebut ada kurang lebih sebanyak 54 Perusahaan Efek. Jika semua harus menghadapi Pengadilan, pasar modal dapat lumpuh seketika karena perdagangan saham akan terganggu dengan peristiwa ini.

Dari kacamata hukum bisnis sebenarnya sederhana saja, jika "dispute" bisnis dapat diselesaikan melalui jalur non litigasi misalnya melalui Arbitrase dan Alternative Dispute ResoIution (ADR) mengapa harus diselesaikan melalui jalur litigasi? Oleh karena itulah di

${ }^{23}$ Suryasin, "Akibat Hukum Transaksi Saham yang Telah Dilaporkan Hilang di Bursa Efek Jakarta", Tesis, (Yogyakarta: Tidak dipublikasikan, UGM, 2003).

${ }^{24}$ Winarto, op. cit. 
dalam hukum bisnis sekarang ini justru berkembang cara-cara penyelesaian "dispute bussiness" di luarjalur pengadilan (out of court settlement atau non litigation) yang disebut dengan Arbitrase dan ADR ini. Bahkan hasil riset membuktikan bahwa $80 \%$ dari sengketasengketa dagang atau bisnis baik berskala nasional maupun internasional berhasil diselesaikan dengan cara konsultasi dan negosiasi yang merupakan salah satu jenis ADR. ${ }^{25}$ Mengapa kalangan businessman lebih menyukai ADR dari pada Pengadilan, karena ADR ada win-win solution bukan win-loose solution, sehingga hubungan bisnis masih dapat dibangun kembali setelah dispute dapat diselesaikan. Berbeda halnya dengan Pengadilan, yang hanya ada win loose solution, sehingga akan berakhir dengan pemutusan hubungan bisnis karena salah satu pihak akan mengalami kekecewaan.

Jika Bapepam mengedepankan edukasi dan menjaga kesinambungan perdagangan dalam kerangka penegakan hukum di Pasar Modal, hal tersebut sudah sejalan dengan keinginan hukum bisnis.yang mengedepankan solusi damai ketimbang jalur yuridis formal. Jika jalur edukasi tidak dapat lagi dilakukan, maka sudah barang tentu harus ditempuh jalur. litigasi. Namun masih disanksikan apakah jika ditempuh jalur litigasi penegakan hukum Pasar Modal juga akan memuaskan (justiciabelen). Ambil contoh, kasus hilangnya saham PT. Gudang Garam Tbk yang divonis antara lain saham dirampas untuk negara. Menjadi pertanyaan, mengapa tidak dikembalikan kepada yang berhak. Jika dirampas untuk negara, apakah saham tersebut nantinya akan dilelang? Kalau dilelang apa kira-kira ada yang mau membeli saham yang sudah pernah menjadi kasus tersebut? Hal-hal seperti ini tampaknya tidak pernah menjadi perhatian hakim atau hakim memang kurang memahami seluk beluk. saham sebagai instrumen bursa. Contoh Jain, pernah menjadi kasus transaksi derivatif dalam bisnis perbankan diputus sebagai gambling, hal seperti itu menunjukkan bahwa masih ada sementara hakim yang memang kurang memahami seluk beluk atau liku-liku hukum dan praktek bisnis pada umumnya apabila bisnis di bursa efek yang sarat dengan "seni" spekulasi dan risiko. Bahkan bisnis di Pasar Modal itu harus "SADIS": sabar dan disiplin. "Patient and discipline is some of keys required to be succeed in financial markef' Itulah prinsip bermain di Pasar Modal.

Harus diakui bahwa tidak ada hukum yang. sempurna di dunia ini. Di sana sini banyak kekurangannya: Tidak ada yang tetap pada hukum kecuali perubahan atau kedinamisan hukum itu sendiri. Begitu telah selesai diundangkan, rumusan pasal-pasal dalam suatu undang-undang memang akan menjadi kata-kata mati, jika tidak dihidupkan oleh pelaku penegak hukum: Sejelek apapun perangkat hukum yang ada, jika penegak hukumnya credible, maka masih dapat diharapkan hasilnya akan baik. Kredibilitas aparat penegak hukum termasuk otoritas bursa efek akan dipertaruhkan jika penyelesaian kasus-kasus hukum yang ada di lingkungan bursa Pasar Modal tidak menghasilkan kepastian hukum, keadilan dan kemanfaatan yang merupakan tiga serangkai "tungku" penegak hukum. ${ }^{26}$

${ }^{25}$ Pramono, op. cit.

${ }^{26}$ Mertokusumo, Sudikno, Mengenal Hukum (Suatu Pengantar) (Yogyakarta: Liberty, 1986). 
Di dalam hukum bisnis, hukuman berupa denda, suspend, sanksi administratif lainnya misalnya penyitaan atas harta kekayaan seseorang pelaku bisnis untuk memulihkan kerugian yang ditimbulkan oleh perbuatannya terhadap orang lain, sebenarnya telah menimbulkan penderitaan pada diri orang itu. Oleh karena itu hendaknya penerapan sanksi pidana dalam kasus-kasus bisnis termasuk kasus-kasus bursa Pasar Modal lebih dipandang sebagai ultimatum remidium untuk memperbaiki kelakuan manusia dan wajarlah apabila orang menghendaki hukum pidana itu di dalam penerapannya haruslah disertai dengan pembatasan yang seketat mungkin. ${ }^{27}$

Di banyak kesempatan baik dalam kuliah maupun dalam seminar-seminar bahwa dalam menghadapi era global sekarang ini sudah - bukan saatnya lagi untuk mempersoalkan mana yang lebih penting antara hukum dan ekonomi. Hukum dan ekonomi dalam banyak hal sudah terbukti selalu saling mengisi kekosongan masingmasing. Hukum dan ekonomi ternyata justru saling mengisi dan saling mempengaruhi, bukan saling bertentangan seperti yang - dilontarkan oleh beberapa ahli baik ahli hukum dan ahli ekonomi pada waktu-waktu yang lalu.

Memang harus diakui, lebih-lebih dalam ега Orde Baru yang lalu banyak kalangan menyadari adanya ketinggalan hukum dalam lalu lintas ekonomi. Hal ini disebabkan oleh bidang ekonomi lebih dahulu untuk mengejar sebesar-besar kemakmuran rakyat. Hal seperti itu memang merupakan salah satu ciri negara berkembang yang lebih menekankan pada pertumbuhan ekonomi dengan sering "mengabaikan" bingkai-bingkai hukum yang harus mengiringinya agar tidak terjadi ketimpangan dan ketidakpastian hukum.

Sekarang ini zaman sudah berubah. Sangat dirasakan betapa hukum sangat didambakan oleh semua orang menjadi panglima dalam pembangunan di era reformasi ini. Oleh karena itu menjadi tanggungjawab anda sekalian untuk memikirkan bagaimana hukum benar-benar mampu menjadi panglima di era reformasi ini. Hukum yang baik dengan pelaksana yang tidak baik, hasilnya pasti jelek, hukum yang kurang baik dengan pelaksana yang baik, hasilnya masih dapat diharapkan baik, hukum yang kurang baik dengan pelaksana yang kurang baik, hasilnya pasti parah dan hukum yang baik dengan pelaksana yang baik, hasilnya pasti baik.

\section{Daftar Pustaka}

Ang, Robbert., Buku Pintar Pasar Modal Indonesia (The Intelligent Guide to Indonesia Capital Market), First Edition, Mediasoft Indonesia, 1997, Homepage: http://www.mediasoftid.com.

Daniri, Mas Ahmad, "Perdagangan Efek Pasca Undang-undang Pasar Modal, Peluang Bisnis dan Tantangan Bidang Hukum", Makalah Bahan Penataran/Diskusi Aspek Hukum Pasar Modal di Indonesia, Yogyakarta:Tidak Dipublikasikan,

${ }^{27}$ Lamintang, Dasar-dasar Hukum Pidana Indonesia (Bandung: Citra Aditya Bakti, 1997). 
Fakultas Hukum UGM, 1997.

, Bursa Efek Demutualisasi Kaitannya Dengan Perubahan UUPM, Makalah Lokakarya Mengenai RUU Pasar Modal, 24 April 2001, Kerjasama Magister Hukum UGM-Bapepam-Jakarta Stock Exchange-University of South Carolina, 2001.

Grinten, Handboek voor de Naamloze en de Besloten Vennootschap, lle druk, met Medewerking van H.J.M.N. Honee, H.M.N. Schonis, W.E.J. Tjeenk Willink, Zwolle, 1976.

Garry, Goodpaster, Tinjauan Terhadap Penyelesaian Sengketa, Seri Dasardasar Hukum Ekonomi Arbitrase di Indonesia, Jakarta: Ghalia Indonesia, 1995.

Gibran, Kahlil, "The Prophet", (terjm) Iwan Nurdaya djafar, Sang Nabi, Yogyakarta: Yayasan Bentang Budaya, 2002.

Houben, Het Certificaat, N.V.H. Van der Marck's Uitgeversimij Roermond, 1951.

Huala, Adolf, "Penyelesaian Sengketa Dagang Dalam WTO", Varia Peradilan Tahun XIII, No.148, Januari, 1998.

Jakarta Stock Exchange, Fact Book 2001, Compiled by Research \&Development Division, Jakarta Stock Exchange, 2001.

Koetin,EA., Analisa Pasar Modal, Jakarta: Pustaka Sinar Harapan, 1993.

Lamintang, Dasar-dasar Hukum Pidana Indonesia, Bandung: Citra Aditya Bakti, 1997.
Mertokusumo, Sudikno, Mengenal Hukum (Suatu Pengantar), Yogyakarta: Liberty, 1986.

Prasetya, Rudhy, Kedudukan Mandiri Perseroan Terbatas Disertai Dengan Ulasan Menurut Undang-undang No. 1 Tahun 1995, Bandung: Citra Aditya Bakti, 1995.

Pramono, Nindyo, Sertifikasi Saham PT Go Public dan Hukum Pasar Modal Di Indonesia, Bandung: Citra Aditya Bakti, 2001.

Pramono, Nindyo, "Optimalisasi Pengembalian Dana Hasil Kejahatan Ekonomi dan KKN Melalui Out of Court Settlement", Makalah, Yogyakarta: Tidak Dipublikasikan, 2003.

Purba, Victor, Perkembangan dan Struktur Pasar Modal Indonesia Menuju Era AFTA 2003, Jakarta: Badan Penerbit Fakultas Hukum Universitas Indonesia, 1999.

Safitri, Indra, Independensi, Transparansi, Pengawasan Kejahatan Pasar Modal, Cet.I, Jakarta: Go Global Book, Safitri \& Co Publication Book Division, 1998.

Syahrir, Tinjauan Pasar Modal, Jakarta: Gramedia Pustaka Utama, 1995.

Schilfgaarde, Van de BV en de NV, Achtste Druk, Gouda Quint, BV, Arnhrm, 1990.

Smallen de. B, 1975, Effecten bedriff, en Effecten verkeer, JH. De Bussy.bv., Amsterdam.

Slagter, Copendium van het Obdernermings Recht, 5e Druk, Kluwer, Deventer, 1990. 
Sutton, David, Understanding The Stock Market, Chicago: Probus Publising Company, Illionis, 1989.

Salamon, Lester, M., The Intemational Guide to Nonprofit Law, New York., Chichester. Weinheim. Brisbane, Singapore, Toronto: John Wiley \& Sons, Inc., 1997.

Soekardono, Hukum Dagang Indonesia, Jilid I, Bagian II, Jakarta: Rajawali Press, 1983.

Sumantoro, Pengantar Tentang Pasar Modal di Indonesia, Jakarta: Ghalia Indonesia, 1990.

, Aspek-aspek Hukum dan Potensi Pasar Modal di Indonesia, Jakarta: Ghalia Indonesia, 1998.

Suryasin, "Akibat Hukum Transaksi Saham Yang Telah Dilaporkan Hilang Di Bursa Efek Jakarta", Tesis, Yogyakarta: Tidak dipublikasikan, UGM, 2003.

Tim Demutualisasi Bapepam, SRO, Draft Kajian Demutualisasi Bursa Efek Indonesia, Jakarta: Tidak Dipublikasikan, 2001.

Tjager, I Nyoman, "Peralihan Hak Atas Saham Melalui Pemindahbukuan Untuk Meningkatkan Efisiensi Dan Kemanan Transaksi Di Bursa Efek", Disertasi, Yogyakarta: Universitas Gadjah Mada, 2003.

Usman, Marzuki, dkk, ABC Pasaar Modal Indonesia, Kerjasama antara lembaga Pengembangan Perbankan Indonesia dengan Ikatan Sarjana Ekonomi Indonesia Cabang Jakarta, 1990.
Vollmar, H.F.A., Het Nederlands Handels Recht, Erste Deel H.D., Tjeenk Willink, Zwolle, 1953.

Winarto, Jasso, Pasar Modal Indonesia Retrospeksi Lima Tahun Swastanisasi BEJ, Jakarta: Pustaka Sinar HarapanJakarta Stock Exchange, 1997.

Whaley, Patrick, J., wt-all., Advising Califormia Nonprofit Corporations, Scond Edition, USA: The Regent of the University of California, 1998.

Yayasan Lembaga Pengembangan Kreativitas dan Pembinaan Disiplin Masyarakat, Almanak Pasar Modala, Jakarta: 1990.

\section{Peraturan Perundang-undangan}

Undang-undang Nomor 86 Tahun 1958 tentang Nasionalisasi Perusahaanperusahaan Belanda di Indonesia.

Undang-undang Nomor 15 Tahun 1952 tentang penetapan "Undang-Undang Darurat tentang Bursa" (Lembaga Negara Nomor 79 Tahun 1951) sebagai Undang-undang.

Undang-undang Nomor 4 Tahun 1971 tentang Perubahan dan Penambahan Atas Ketentuan Pasal 54 Kitab Undangundang Hukum Dagang (Stbl. 1847: 23).

Undang-undang Nomor 1 Tahun 1995 tentang Perseroan Terbatas.

Undang-undang Nomor 8 Tahun 1995 tentang Pasar Modal.

Undang-undang Nomor 7 Tahun 1997 tentang Dokumen Perusahaan. 
Undang-undang Nomor 4 Tahun 1998 tentang Penetapan Perpu Nomor 1 Tahun 1998 tentang Perubahan Undangundang Kepailitan menjadi Undangundang.

Undang-undang Nomor 5 Tahun 1999 tentang Larangan Praktek Monopoli dan Persaingan Usaha Tidak Sehat.

Peraturan Pemerintah Nomor 25 Tahun 1976 tentang Penyertaan Modal Negara Republik Indonesia Untuk Pendirian Perusahaan Perseroan (Persero) "Danareksa".

Keputusan Presiden Nomor 52 Tahun 1976 tentang Pasar Modal sebagaimana telah disempurnakan dengan
Keputusan Presiden Nomor 58 Tahun 1984.

Keputusan Presiden Nomor 60 Tahun 1988 tentang Pasar Modal.

Keputusan Presiden Nomor 53 Tahun 1990 tentang Pasar Modal.

Surat Keputusan Menteri Keuangan Nomor Kep. 1548/KMK.013/1990 tentang Pasar Modal.

Surat Keputusan Menteri Keuangan Nomor 1199/KMK.010/1991 tentang Perubahan Keputusan Menteri Keuangan Republik Indonesia Nomor 1548/KMK.013/1990 tentang Pasar Modal. 